\title{
MEASUREMENT OF SUCCESS IN THE INTEGRATED PRESCRIBING INFORMATION SYSTEM AT ANANDA BEKASI HOSPITAL
}

\author{
Ferdi Novalendo*)1, Rizal Syarief*), and Arif Imam Suroso*) \\ *) School of Business, Bogor Agricultural University \\ Jl. Raya Pajajaran, Bogor 16151
}

\begin{abstract}
Electronic prescribing is highly useful for hospitals to reduce the error level of prescribing medicine to patients. Currently, a large number of prescribing errors are made by doctors to patients; however, there are also patients who are disobedient to prescriptions made by doctors. This research aims to evaluate whether the prescription information system at Ananda Bekasi Hospital can be evaluated to be successful and has a positive impact on the performance of doctors to patients. The study was conducted on the success of integrated prescribing information system at Ananda Bekasi Hospital using the theoretical framework of DeLone \& McLean's information system model. Data processing was conductedby using SEM-PLS method. Aspects of technology analyzed in determining prescription information systems include system quality, information quality, service quality, usage intention, user satisfaction, and net benefits. Referring to the technological aspects, the research results on prescribing information system are as follow: information quality influences the usage intention and user satisfaction, and usage intention and user satisfaction influence the net/benefit. Hence, the results of the research show that the information system success model of DeLone and McLean is not fully proven empirically to be successful in the prescibing information system in Ananda Bekasi Hospital.
\end{abstract}

Keywords: DeLone \& McLean, Information System Success, user satisfaction, prescribing information systems, SEM-PLS.

\begin{abstract}
Abstrak: Peresepan elektronik sangat berguna bagi rumah sakit untuk mengurangi tingkat kesalahan pemberian resep kepada pasien. Saat ini banyak kesalahan peresepan yang dilakukan oleh dokter kepada pasien, namun juga banyak pasien yang tidak patuh terhadap peresepan yang dibuat oleh dokter. Penelitian ini bertujuan untuk mengevaluasi apakah sistem informasi peresepan di Rumah Sakit Ananda Bekasi dapat dikatakan berhasil atau sukses, dan mempunyai dampak positif terhadap kinerja dokter kepada pasien. Penelitian dilakukan terhadap kesuksesan sistem informasi peresepan terintegrasi di Rumah Sakit Ananda Bekasi dengan menggunakan kerangka teori model kesuksesan sistem informasi DeLone \& McLean. Pengolahan data dilakukan dengan menggunakan metode SEM-PLS. Aspek teknologi yang dianalisis dalam menentukan sistem informasi peresepan meliputi kualitas sistem, kualitas informasi, kualitas layanan, niat penggunaan, kepuasan pengguna dan manfaat bersih. Dilihat dari aspek teknologi, hasil penelitian mengenai sistem informasi peresepan dilihat dari aspek teknologi adalah sebagai berikut : kualitas informasi mempengaruhi niat penggunaan dan kepuasan pengguna, niat penggunaan dan kepuasan pengguna mempengaruhi manfaat bersih. Dari aspek tersebut hasil penelitian menunjukkan bahwa model kesuksesan sistem informasi DeLone dan McLean tidak sepenuhnya terbukti secara empiris pada sistem informasi peresepan di Rumah Sakit Ananda Bekasi.
\end{abstract}

Kata kunci: DeLone \& McLean, kesuksesan sistem informasi, kepuasan pengguna, sistem informasi peresepan, SEM-PLS

\footnotetext{
${ }^{1}$ Corresponding author:

Email: fnovalendo@gmail.com
} 


\section{INTRODUCTION}

The development of information technology is currently helpful for hospital management in managing hospitals. The evident benefit of using the information system in the hospital is to help every health service unit in making monthly and annual reports for the hospital management, store data of patients coming for treatment to the hospital, help the hospital management in making reports on the hospital development of the undesired events on patients after seeing a doctor to the health department. The Canadian Medical Association (CMA) recommends an electronic health record containing drug prescription modules regulated in physician practice places and health centers (Eggertson, 2009). In the United States, there is a software with an electronic drug program that warns when side effects interact with other drugs on patients (Ammenewerth et al. 2008).

One of the information systems required today by the hospital management is the electronic prescribing information system. A study on doctors in Sweden obtained the following results: The electronic prescribing information system was easy to use (88\%), electronic information systems would make better services $(92 \%)$ and reduce service time $(83 \%)$ compared to hand-written prescriptions (Hellstrom et al. 2009). In addition, there is also a study on increasing patient compliance to the use of electronic prescriptions rather than hand-written prescription. It was conducted in two-time ranges; i.e. 10 days and 60 days. Within 10 days, the percentage of electronic prescribing information system usage compared to hand-written prescription was $57.2 \%$ (electronic prescription) and $46.2 \%$ (hand-written prescription), while in the span of 60 days, the percentage of the use of electronic prescribing information system compared to hand-written prescription was $78.2 \%$ (electronic prescription) and $60.8 \%$ (hand-written prescription), and more details can be seen in Figure 1 (MacReady, 2016).

Furthermore, the research results conducted by Hellstrom et al. (2009), MacReady (2016) and Susanti (2013) state that the application of prescribing information systems can reduce prescribing errors made by doctors to patients and improve patient compliance with prescribing doctors. This becomes the reason of the requirement for research on the application of prescribing information systems taking place at the Ananda Hospital in Bekasi. The application of this information system becomes a necessity; therefore, the success of its implementation needs to be evaluated.

Based on the background of the requirement for research on the application of prescribing information systems taking place at the Ananda Hospital in Bekasi, there are 3 research objectives to obtain the maximum evaluation results to be recommended to the hospital management. The objectives of this research are to analyze the net benefits of the application of prescribing information systems at Ananda Bekasi Hospital, analyze factors influencing the success of prescribing information systems and the relationship of success factors in prescribing information systems at Ananda Bekasi Hospital, and analyze efforts to improve and increase the success of the prescribing information system in the future at Ananda Hospital Bekasi. The population used in research included specialist doctors, general practitioners, and dentists who used integrated prescribing information systems at Ananda Hospital in Bekasi.

\section{METHODS}

This research was conducted in the Pharmacy Installation section of Ananda Bekasi Hospital, located at Sultan Agung Street No. 173, Medan Satria Bekasi district. The research, data processing, and thesis writing were carried out for 3 months starting from August to October 2017.

The data of this research were primary data using interval scale collected through questionnaires to specialist doctors, general practitioners and dentists who used integrated prescribing information systems at Ananda Hospital Bekasi. Questionnaire is a data collection technique in which there is a written communication between the data collectors (the researchers) and respondents. The questionnaire was given to comprehend the extent to which technology, people, organizations and benefits influence the use of integrated prescribing information systems at Ananda Bekasi Hospital. 


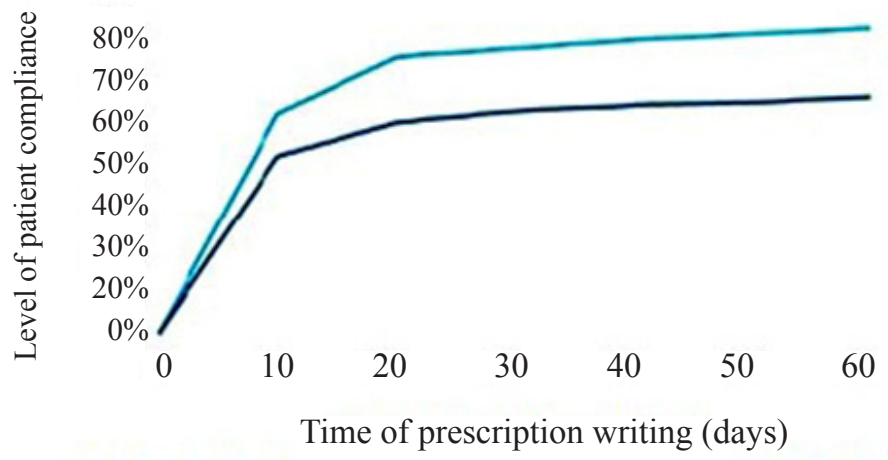

Figure 1. Graph the level of patient compliance between the Electronic Prescribing System and Prescribing System using prescription paper (MacReady, 2016)

This research used closed a question questionnaire in which the answers to the questions were provided in the questionnaire, so that the respondents only chose an answer in accordance with the current conditions. The questions in this questionnaire were related to the integrated prescribing information system analysis at Ananda Hospital in Bekasi based on the construct variable framework of DeLone and McLean's information system success model 2003 that were tested and analyzed. Data processing and analysis techniques used in this study were:

\section{Structural Equation Modeling (SEM)}

The analysis used in the research was Structural Equation Modeling (SEM). SEM is a statistical method capable of analyzing the relationship pattern of latent variables and indicators, the relationship of latent and other latent variables and analyzing measurement errors directly (Yamin and Kurniawan, 2009).

There are two types of SEM widely used in various types of research i.e. covariance-based SEM (CBSEM) and partial least squares SEM (PLS-SEM). PLS is an alternative method with a variant-based or component-oriented model approach, while CBSEM is a covariant-based SEM method oriented to the making of analytical models and requires a strong theoretical basis of a causal relationship model (Yamin and Kurniawan, 2009).

\section{Partial Least Squares (PLS)}

The analytical tool used in the study was PLS-SEM. The data were processed using SmartPLS software version 3.2.6. In PLS-SEM analysis, and the amount of data is not a problem in which the minimum of 30 data to the use of 113 data in the research can be accepted. Hair et al. (2014) state that there are three stages of data analysis using PLS with three necessary stages in using PLS i.e.:

\section{Model specification}

This stage relates to the preparation of the outer and inner models. Inner or structural model shows the relationship between variables evaluated, while the outer or measurement model is used to evaluate the relationship between the latent variables and indicators. The first step in using PLS involves creating a path model connecting indicators and latent variables based on theory and logic (Hair et al. 2014). The notations used in the model are as follows (Latan and Ghozali, 2012; Jaya and Sumertajaya, 2008): x (Indicator of exogenous latent variable); y (Indicator of endogen latent variable); $\xi$ (Ksi, exogenous latent variable); $\eta$ (Eta, endogen latent variable); $\lambda x$ (Lamda (small), outer loading of exogenous latent variable); $\lambda y$ (Lamda (small), outer loading of endogen latent variable); $\Lambda \mathrm{x}$ (Lamda (big), outer loading matrix of exogenous latent variable); $\Lambda$ y (Lamda (big), outer loading matrix of endogen latent variable); B (Beta, coefficient of the effect of endogen variable on endogen variable); $\gamma$ (Gamma, coefficient of the effect of exogenous variable 
on endogen variable); $\varsigma$ (Zeta (small), model galat); $\delta$ (Delta (small), measurement galat on exogenous latent variable); $\varepsilon$ (Epsilon (small), measurement galat on endogen latent variable).

\section{Measurement Model Evaluation}

In the measurement model, there are two kinds of relationship indicators i.e. reflective and formative. Evaluations carried out on measurement models with reflective indicators include convergent validity, discriminant validity, and composite reliability (Hair et al. 2011). Meanwhile, the measurement model with formative evaluation indicators cover the wights of indicators and multicolliniearity (Hair et al. 2011). In general, the reflective indicator model equation can be shown as follows (Jaya and Sumertajaya, 2008; Latan and Ghozali, 2012):

$$
\mathrm{x}=\Lambda \mathrm{x} \xi+\delta ; \mathrm{y}=\Lambda \mathrm{y} \eta+\varepsilon
$$

in which $\mathrm{x}$ and $\mathrm{y}$ are exogenous and endogenous latent indicators, while $\Lambda \mathrm{x}$ and $\Lambda \mathrm{y}$ are loading matrices describing simple regression coefficients that connect the latent variables to the indicators. Residuals measured by $\delta$ and $\varepsilon$ can be interpreted as measurement errors. Specifically, the equation for the research measurement model can be shown as follows:

\begin{tabular}{|c|c|c|c|}
\hline IQ1 & $: \quad \lambda x_{1} \xi 1+\delta_{1}$ & SERV_Q1 & $\lambda \mathrm{x}_{18} \xi 3+\delta_{18}$ \\
\hline IQ2 & $: \quad \lambda \mathrm{x}_{2} \xi 1+\delta_{2}$ & SERV_Q2 & $\lambda \mathrm{x}_{19} \xi 3+\delta_{19}$ \\
\hline IQ3 & $: \quad \lambda x_{3} \xi 1+\delta_{3}$ & SERV_Q3 & $\lambda \mathrm{x}_{20} \xi 3+\delta_{20}$ \\
\hline IQ4 & $: \lambda \mathrm{x}_{4} \xi 1+\delta_{4}$ & SERV_Q4 & $\lambda \mathrm{x}_{21} \xi 3+\delta_{21}$ \\
\hline IQ5 & $: \lambda \mathrm{x}_{5} \xi 1+\delta_{5}$ & SERV_Q5 & $\lambda \mathrm{x}_{22} \xi 3+\delta_{22}$ \\
\hline IQ6 & $: \lambda \mathrm{x}_{6} \xi 1+\delta_{6}$ & SERV_Q6 & $\lambda \mathrm{x}_{23} \xi 3+\delta_{23}$ \\
\hline SQ1 & $: \lambda x_{7} \xi 2+\delta_{7}$ & IU1 & $\lambda y 1 \eta 1+\varepsilon 1$ \\
\hline SQ2 & $: \lambda \mathrm{x}_{8} \xi 2+\delta_{8}$ & IU2 & $\lambda y 2 \eta 1+\varepsilon 2$ \\
\hline SQ3 & $: \quad \lambda x_{9} \xi 2+\delta_{9}$ & IU3 & $\lambda y 3 \eta 1+\varepsilon 3$ \\
\hline SQ4 & $: \lambda \mathrm{x}_{10} \xi 2+\delta_{10}$ & IU4 & $\lambda y 4 \eta 1+\varepsilon 4$ \\
\hline SQ5 & $: \lambda \mathrm{x}_{11} \xi 2+\delta_{11}$ & IU5 & $\lambda y 5 \eta 1+\varepsilon 5$ \\
\hline SQ6 & $: \lambda x_{12} \xi 2+\delta_{12}$ & U1 & $\lambda y 6 \eta 2+\varepsilon 6$ \\
\hline SQ7 & $: \lambda x_{13} \xi 2+\delta_{13}$ & $\mathrm{U} 2$ & $\lambda y 7 \eta 2+\varepsilon 7$ \\
\hline SQ8 & $: \lambda x_{14} \xi 2+\delta_{14}$ & U3 & $\lambda y 8 \eta 2+\varepsilon 8$ \\
\hline SQ9 & $: \lambda \mathrm{x}_{15} \xi 2+\delta_{15}$ & $\mathrm{U} 4$ & $\lambda y 10 \eta 2+\varepsilon 10$ \\
\hline SQ10 & $: \lambda x_{16} \xi 2+\delta_{16}$ & NB1 & $\lambda y 11 \eta 3+\varepsilon 11$ \\
\hline SQ11 & $: \quad \lambda x_{17} \xi 2+\delta_{17}$ & NB2 & $\lambda y 12 \eta 3+\varepsilon 12$ \\
\hline & & NB3 & $\lambda y 13 \eta 3+\varepsilon 13$ \\
\hline
\end{tabular}

\section{Structural Model Evaluation}

The structural model shows the relationship or estimation strength between latent variables based on the substantive theory (Latan and Ghozali, 2012). Structural model evaluation was carried out to ensure that the structural model built was accurate (Hussein, 2015). Structural models were evaluated by referring to R-square values (Hair et al. 2014). Structural model evaluation also included hypothesis testing in reference to the path coefficients and t-values (Hair et al. 2014). In general, the structural model equation can be written as follows (Jaya and Sumertajaya, 2008; Latan and Ghozali, 2012):

$$
\eta=\beta \eta+\Gamma \xi+\varsigma
$$

in which $\eta$ is an endogenous latent variable vector, $\xi$ is an exogenous latent variable vector, and $\varsigma$ is a residual vector. According to Latan and Ghozali (2012), PLS is designed for recursive models so that the relationship between exogenous and endogenous latent variables is often called a causal chain system which can be specified as follows:

$$
\eta j=\Sigma i \beta j i \eta i+\Sigma i j j b \xi b+\varsigma j
$$

in which $\gamma \mathrm{jb}$ (in the form of matrix denoted by $\Gamma$ ) is the path coefficient that connects the endogenous latent variables $(\eta)$ to exogenous latent variables $(\xi)$. Meanwhile, $\beta \mathrm{ji}$ (in the form of a matrix denoted by $\beta$ ) is a path coefficient that connects endogenous latent variables to other endogens. The index ranges used are $i$ and $b$, and the parameter $s j$ is the inner residual variable. Specifically, the equation for the structural model can be written as follows:

$$
\begin{array}{r}
\eta 1=\gamma 1 \xi 1+\gamma 3 \xi 2+\gamma 5 \xi 3+\varsigma 1 \\
\eta 2=\gamma 2 \xi 1+\gamma 4 \xi 2+\gamma 6 \xi 3+\varsigma 2 \\
\eta 3=\beta 1 \eta 1+\beta 2 \eta 2+\varsigma 3
\end{array}
$$

The research of integrated prescribing information system at Ananda Bekasi Hospital using the DeLone and McLean's IS Success model (2003) framework approach reflects the dependence of 6 measurement variables to be evaluated i.e. information quality, system quality, service quality, intention to use, user satisfaction, and net benefits. Moreover, the data analysis was conducted by using SEM with the help of SmartPLS 3 software. The framework of the research carried out can be seen in Figure 2. 


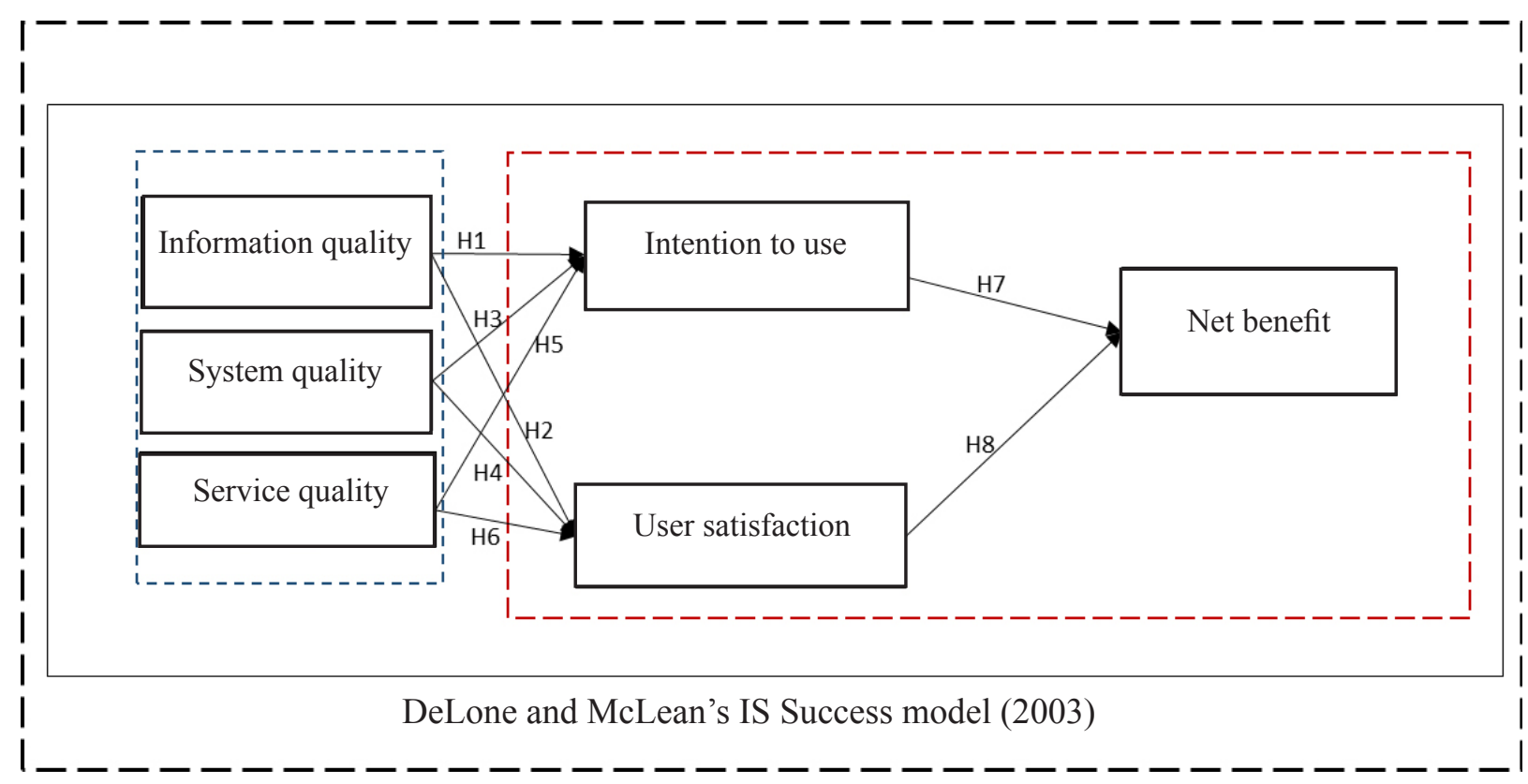

Figure 2. Research framework

\section{RESULTS}

Analysis on the influences among the latent variables in this research was carried out using the help of PLS analysis tools (Inscription, 2016). This research tool was selected with a consideration to obtain a more comprehensive and ideal picture related to the influence on each construct built through path analysis. This research also tested the validity and reliability of each latent variable including the variables of information quality, system quality, and service quality, intention to use, user satisfaction, and net benefits by using the SmartPLS software.

\section{Model Specification}

The research model is based on the DeLone and McLean's information system success model (2003), and the results of the research model specifications can be seen in Figure 3.

\section{Measurement Model Evaluation}

Evaluation on this measurement model (outer model) is an evaluation carried out to specify the relationship between latent variables and their indicators. In other words, the measurement model (outer model) defines how each indicator relates to its latent variables. The tests conducted on the measurement model (outer model) for reflective indicators in this research were convergent validity, discriminant validity, composite reliability, average variance extracted (AVE), and Cronbach alpha.

In evaluating the measurement model (outer model), there is a validity test examining the convergent validity and discriminant validity. In convergent validity, the loading factor value and AVE value are 0.5 or above (Ghozali, 2008). Based on the final results of the research model processing by using SmartPLS software, we can see in Figure 4 that the loading factor values for most indicators are above 0.5 , while the AVE values of each variable in Table 1 are above 0.5. Based on the loading factor value in Figure 4 and the AVE value shown in Table 1, the indicators used in this study have fulfilled convergent validity and can be used for further analysis. Furthermore, reliability testing can be tested in two ways, namely, examining the composite reliability value and Cronbach's alpha value. Composite reliability examines the reliability values of indicators in a construct, while Cronbach's alpha is used to strengthen the reliability of indicators in all constructs. A construct or variable is considered to meet the composite reliability if it has a composite reliability value by $>0.7$ and the value of cronbach's alpha by $>0.6$. In table 1 above, we can see the research results that show the composite reliability values for all variables are above 0.7 and the cronbach's alpha values for all variables are above 0.6 so that they meet the requirements. 


\section{Structural Model Evaluation}

Each $\mathrm{R}$ square value on endogen latent variables of $0.75,0.50$, and 0.25 represents a substantial, medium, and weak accuracy level (Hair et al. 2011). In table 1, it is evident that the $\mathrm{R}$ square value of user satisfaction variable is 0.813 . This variable is explained by information quality, system quality, and service quality. Therefore, it can be said that these variables are able to explain user satisfaction by $81.3 \%(0.813 \times 100 \%)$, while the remaining $18.7 \%(100 \%$ - $18.7 \%)$ is explained by other variables outside the scope of research. $\mathrm{R}$ square value explanation in Table 1 similarly applies to other variables. Intention to use and user satisfaction variables are able to explain the net benefit variable by $78.3 \%$. The variables of information quality, system quality, and service quality are able to explain the intention to use variable by $22.8 \%$.

In the following step, in structural model evaluation, hypothesis testing was performed by looking at the path coefficients, t-values, and $p$-values obtained after bootstrapping the studied model. The level of significance for each hypothesis was measured based on the T-table value for 71 data. If the level of significance is high $(99 \%$ or $\mathrm{p}<0.01)$, the t-value should be $\geq 2.36$, in moderate significance level $(95 \%$ or $p<0.05)$, the $\mathrm{t}$-value is $\geq 1.66$, and in low significance level $(90 \%$ or $p<0.1$ ), the $t$-value should be $\geq 1.29$. Evaluations of path coefficient values, t-values, and significance of hypotheses can be seen in Table 2.

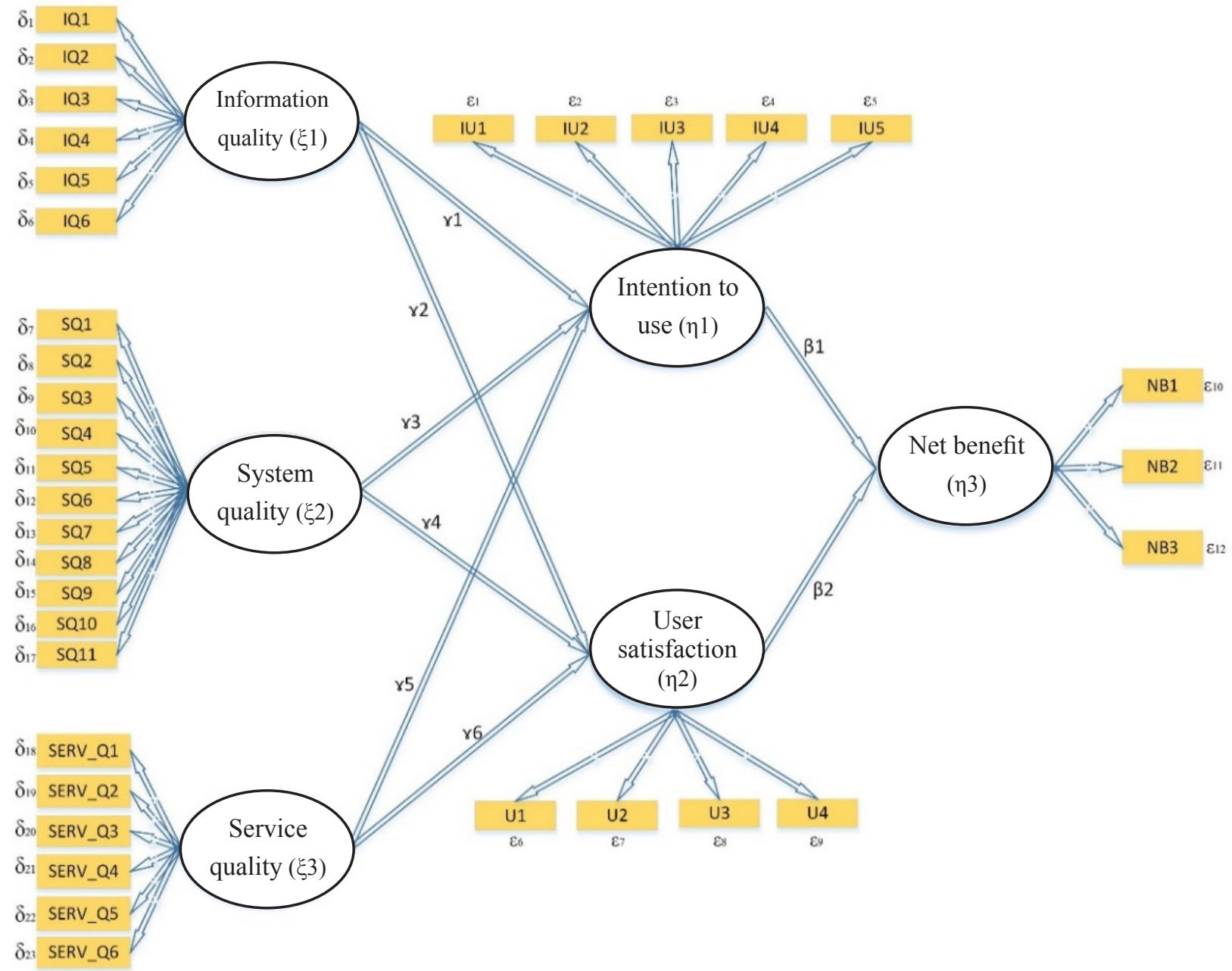

Figure 3. Path diagram 


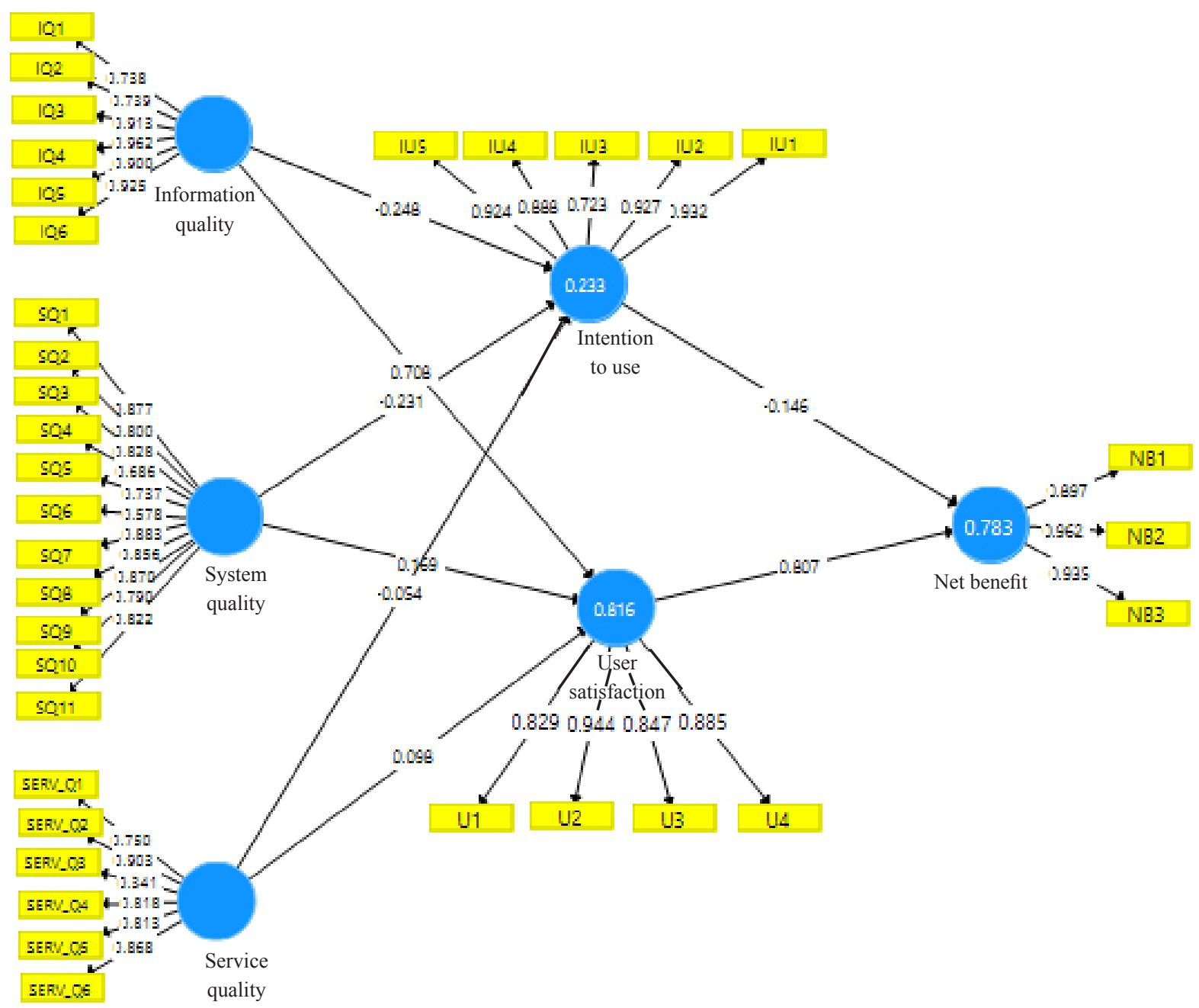

Figure 4. The final results of research model processing by SmartPLS

Table 1. Values of AVE, Composite Reliability, R-Square, and Cronbach Alpha

\begin{tabular}{lcccc}
\hline Latent variables & Cronbach's Alpha & Composite Reliability & AVE & R Square \\
\hline User satisfaction & 0.899 & 0.930 & 0.77 & 0.813 \\
Information quality & 0.934 & 0.948 & 0.753 & \\
Service quality & 0.901 & 0.927 & 0.719 & \\
System quality & 0.946 & 0.955 & 0.702 & \\
Net benefit & 0.924 & 0.952 & 0.868 & 0.783 \\
Intention to use & 0.927 & 0.946 & 0.779 & 0.228 \\
\hline
\end{tabular}

Table 2. Hypothesis testing

\begin{tabular}{llcccc}
\hline Hypothesis & \multicolumn{1}{c}{ Relationships among variables } & $\begin{array}{c}\text { Path } \\
\text { coefficients }\end{array}$ & T-value & P Values & $\begin{array}{c}\text { Keputusan } \\
\text { Hipotesis }\end{array}$ \\
& Information quality $\rightarrow$ Intention to use & -0.313 & 1.783 & $0.075^{*}$ & Accepted \\
H1 & Information quality $\rightarrow$ User satisfaction & 0.736 & 7.39 & $0.000^{* * *}$ & Accepted \\
H3 & System quality $\rightarrow$ Intention to use & -0.171 & 0.833 & $0.405(\mathrm{ts})$ & Not accepted \\
H4 & System quality $\rightarrow$ User satisfaction & 0.172 & 1.424 & $0.155(\mathrm{ts})$ & Not accepted \\
H5 & Service quality $\rightarrow$ Intention to use & -0.074 & 0.482 & $0.630($ ts $)$ & Not accepted \\
H6 & Service quality $\rightarrow$ User satisfaction & 0.054 & 0.981 & $0.327(\mathrm{ts})$ & Not accepted \\
H7 & Intention to use $\rightarrow$ Net benefit & -0.159 & 1.829 & $0.068^{*}$ & Accepted \\
H8 & User satisfaction $\rightarrow$ Net benefit & 0.800 & 11.984 & $0.000^{* * *}$ & Accepted \\
\hline
\end{tabular}


Based on Table 2, information quality variable negatively influences the intention to use variable with a low level of significance $(\beta=-0313, p=0.075)$ so that $\mathrm{H} 1$ is accepted and information quality variable also influences the user satisfaction variable so that $\mathrm{H} 2$ is accepted. The system quality variable on the intention to use $(\beta=-0.171, \mathrm{p}=0.833)$ and the system quality on user satisfaction $(\beta=0.172, p=0.155)$ have negative effects so that $\mathrm{H} 3$ and $\mathrm{H} 4$ are not accepted. Service quality variable on intention to use $(\beta=-0.174$, $\mathrm{p}=0.482)$ and service quality on user satisfaction $(\beta=$ $0.054, \mathrm{p}=0.327$ ) have negative effects so that $\mathrm{H} 5$ and $\mathrm{H} 6$ are also not accepted. Intention to use variable on net benefits $(\beta=-0.159, p=0.068)$ and user satisfaction on net benefits $(\beta=0.800, p=0.000)$ have positive effects so that $\mathrm{H} 7$ and $\mathrm{H} 8$ are accepted.

\section{Analysis of Net Benefits on the Application of Prescribing Information System}

The results of the research in Table 1 show that R-square value of the net benefit variable of the prescribing information system is $78.3 \%$, meaning that the accuracy used in the research is substantial. There are still $21.7 \%$ of the influence of other net benefit variables that are not described in the study. Based on the indicators on the net benefits, the most influential indicator in the prescribing information system is benefit that explains the efficiency of the system in supporting the work done by doctors and in providing efficient waiting time for patients to take drugs.

\section{Success Factors on Prescribing Information System}

The prescribing information system used in the study shows that the net benefits in the application of prescribing information systems are influenced by intention to use and user satisfaction. Intention to use has an effect on net benefits with a low level of significance in contrast to user satisfaction with a high level of significance. Therefore, in prescribing information systems, user satisfaction is the most influencing variable for the success of prescribing information systems, and satisfaction indicator is influential that explains that information needs have been met. Information quality in prescribing information systems can provide information in a short time. As the data of patient information needed by the doctor can be obtained quickly, the efficiency of waiting time for taking drugs by patients can take place.

\section{Managerial Implications}

More specifically, some recommended managerial implications to the Ananda Bekasi hospital management related to the results of research on the analysis of the success of integrated information systems in Ananda Bekasi hospital viewed from the technological aspects can be seen as follows: Referring to the analysis of the success of prescribing information system at Ananda Bekasi Hospital, the information quality is the variable that most influences the overall prescribing information system. Intentions to use consisting of the daily use, frequency of use, feedback, patterns of navigation, and nature of usage are things that can attract doctors' attention in using the prescription system. User satisfaction in the application of prescribing information systems is in accordance with the needs of doctors to improve functionality in Ananda Bekasi Hospital. Referring to the net benefits, by using the prescribing information system, doctors can foster creativity, obtain the benefits of prescribing systems, and have problemsolving abilities at Ananda Hospital in Bekasi.

\section{CONCLUSIONS AND RECOMMENDATIONS}

\section{Conclusions}

Based on the results of the research, the net benefits are strongly influenced by the intention to use and satisfaction of prescribing information system users. The factors that influence the success of prescribing information systems are: information quality, intention to use, user satisfaction, and net benefits. The relationship of the factors influencing the success of the prescribing information system is that the information quality influences user satisfaction and intention to use, user intention and satisfaction influence the net benefits. Based on the research results, efforts to improve the prescribing information system in the future are focused on prescribing information system users, for user satisfaction is strongly influenced by information quality, usage intentions, user satisfaction, and net benefits.

\section{Recommendations}

Future research is expected to improve the system quality that can affect the success of prescribing information systems, and the existing service quality can be improved. The effort to improve the success 
of the future prescribing information system at Ananda Bekasi Hospital is modifying the prescribing information system and service quality to improve system capabilities so that the system used is more effective and can be used by users as needed.

\section{REFERENCES}

Ammenwerth E, Inderst PS, Machan C, Siebert U. 2008. The effect of electronic prescribing on medication errors and adverse drug events: a systematic review. Journal of the American Medical Informatics Association 15(5): 585600. https://doi.org/10.1197/jamia.M2667.

DeLone W, McLean ER. 1992. Information system success: the quest for the dependent variable. Information System Research 3(1): 1-37. https:// doi.org/10.1287/isre.3.1.60.

DeLone W, McLean ER. 2003. The DeLone and McLean model of information system success: a ten year update. Journal of MIS 19 (4): 9-30.

Eggertson L. 2009. Canada lags US in adoption of e-prescribing. Canadian Medical Association Journal 180(9): E.25-E.26.

Fornell C, Larcker DF.1981. Evaluating structural equation models with unobservable variables and measurement error. Journal of Marketing Research 18(1): 39-50. https://doi. org/10.2307/3151312.

Ghozali I. 2008. Aplikasi Analisis Multivariate dengan Program SPSS. Semarang: Badan Penerbit Universitas Diponegoro.

Hair JF, Ringle CM, Sarstedt M. 2011. PLS-SEM: indeed a silver bullet. Journal of Marketing Theory and Practice 19(2):139-151.https://doi. org/10.2753/MTP1069-6679190202

Hair JF, Sarstedt M, Hopkins L, Kuppelwieser VG. 2014. Partial least squares structural equation modeling (PLS-SEM). European Business Review 26(2):106-121.https://doi.org/10.1108/ EBR-10-2013-0128

Hamilton S, Chervany NL. 1981. Evaluating information system effectiveness - part 1: comparing evaluation approaches. MIS Quartely 5(3): 55-69. https://doi.org/10.2307/249291

HellstromLM,Petersson G,Astrand B. 2009.Physician's attitudes towards e-prescribing- evaluation of a Swedish full-scale implementation. $B M C$ Medical Informatics and Decision Making
9(37): $1-10$.

Ishman MD. 1996. Measuring information success at the individual level in cross cultural environments. Information Resources Management Journal 9(4): 16-28. https://doi.org/10.4018/ irmj.1996100102.

Jaya IGNM, Sumertajaya IM. 2008. Pemodelan PersamaanStrukturaldenganPartialLeastSquare. Seminar Nasional Matematika dan Pendidikan Matematika. Yogyakarta: Universitas Negeri Yogyakarta. hlm 118-132.; [2018 January13].

Latan H, Ghozali I. 2012. Partial Least Squares: Konsep, Teknik dan Aplikasi Menggunakan Program SmartPLS 2.0 M3. Semarang: Badan Penerbit Universitas Diponegoro.

Lee YE, Benbasat I. 2003. Interface design for mobile commerce. Communication of The ACM 46(12): 48-52. https://doi.org/10.1145/953460.953487.

Lin HF, Lee GG. 2006. Determinants of success for online communities: an empirical study. Behaviour and Information Technology 25(6): 479-488. https:// doi.org/10.1080/01449290500330422.

Livari J. 2005. An empirical test of the model of information system success. The Data Base for Advances In Information Systems Journal 36(2): 8-27. https://doi.org/10.1145/1066149.1066152.

MacReady N. 2016. E-prescribing increases medication adherence. http: www.physiciansweekly.com. [13 Januari 2018].

McGill T, Hobbs V, Klobas J. 2003. User developed applications and information system success: a test of DeLone \& McLean's model. Information Resources Management Journal (IRMJ) 16(1): 24-45. https://doi.org/10.4018/ irmj.2003010103.

Satzinger JW, Olfman L. 1998. User interface consistency across end-user applications: the effects on mental models. Journal of Management Information System 14(4): 167-193. https://doi. org/10.1080/07421222.1998.11518190.

Susanti I. 2013. Identifikasi medication error pada fase prescribing, transcribing, dan dispensing di depo farmasi rawat inap Penyakit Dalam gedung Teratai, Instalasi Farmasi RSUP Fatmawati periode 2013. [skripsi]. Jakarta: UIN Syarif Hidayatullah.

Yamin S, Kurniawan H. 2009. Structural Equation Modeling: Belajar Lebih Mudah Teknik Analisis Data Kuesioner dengan Lisrel - PLS. Jakarta: Salemba Infotek. 